\title{
A INTERNACIONALIZAÇÃO DA PESQUISA EM PSICANÁLISE
}

A razão deste número especial da revista Ágora foram dois colóquios internacionais realizados pelo Programa de Pós-Graduação em Teoria Psicanalítica, em colaboração com universidades e centros de pesquisa avançada na França. O primeiro, ocorrido em maio de 2013, intitulado 'Subjetividades e montagens corporais no mundo contemporâneo', se realizou em colaboração com o Centre de Recherches Psychanalyse Médecine et Société, da Université Paris Diderot. O segundo, em outubro de 2013, intitulado 'Dependência e drogas na adolescência: entre subjetividade e cultura', ocorreu em colaboração com o Collège International de L’Adolescence e da Université Paris Descartes.

O que tais eventos evidenciam é a intensa relação de colaboração entre o Programa de Pós-Graduação em Teoria Psicanalítica e algumas universidades francesas, que se realiza pelo intercâmbio de pesquisadores provenientes dos dois lados do Atlântico e que revelam efetivamente um novo paradigma de trocas de conhecimento em que a internacionalização da pesquisa se impõe de maneira indiscutível.

O saldo desse intercâmbio se revela na ativa produção de conhecimento em teoria psicanalítica e saberes afins, provenientes de diferentes setores das ciências humanas e da filosofia, que se conjugam de maneira criativa, de forma a criar novos objetos e novas problemáticas de investigação. Assim, este número especial de Ágora visa intencionalmente dar mostras desta produção conjunta, de maneira a documentar não apenas o espírito de colaboração científica, mas também a produção efetiva que foi realizada.

É preciso dizer, também, que este número especial de Ágora segue estritamente os critérios de seleção de artigos, isto é, os artigos encaminhados pelo conselho científico da revista foram submetidos à avaliação, como se faz em todo e qualquer número regular da revista. Vale dizer: não se aceitaram os artigos simplesmente porque foram apresentados nos referidos colóquios, mas sim porque passaram por uma apuração acurada de nossos pareceristas. Ademais, mantivemos o caráter bilíngue desta produção, publicando alguns artigos em português e outros em francês, de acordo com a origem e a procedência dos colaboradores.

Esperamos que desta maneira possamos tornar mais viva a relação de colaboração com os nossos parceiros internacionais, da mesma forma que eles o fazem 
com a publicação em revistas e livros franceses de artigos oriundos do Programa de Pós-Graduação em Teoria Psicanalítica, caracterizando assim um produtivo espírito de troca sem privilégios de nenhum dos lados implicados nestes acordos entre a Universidade Federal do Rio de Janeiro, a Université Denis Diderot e a Université René Descartes.

Em nome da pesquisa em teoria psicanalítica, conjugada com saberes afins, esperamos que esta publicação contribua para o enriquecimento de nosso diálogo e de nossas trocas para além das fronteiras brasileiras, e que incremente o dito paradigma de internacionalização da pesquisa.

Joel Birman 